\title{
PROBLEMS OF MANAGEMENT AND MARKETING
}

Жихарева-Толстік Г. О., аспірант

Даценко В. В., к.е.н., доцент

Університет митної справи та фінансів м. Дніпро, Україна

DOI: https://doi.org/10.30525/978-9934-26-018-6-18

\section{МАРКЕТИНГ, ЯКИЙ ФОРМУЄ ОЦІНКУ СПОЖИВАЧА, ТРИ КЛАСИЧНИХ МАРКЕТИНГОВИХ ПОКАЗНИКА}

Вимірювання - ефективний інструмент, і вони допомагають не тільки підвищити ефективність маркетингу, а й істотно змінити стиль роботи організації - за умови грамотного використання правильних показників. Переважна більшість організацій не беруть участь у творчій роботі, а замість цього керують маркетинговим процесом. Потрібно обдумати, які показники дійсно важливі для певного типу маркетингової діяльності. Маркетинг, спрямований на створення проінформованості, має безліч форм: телевізійна реклама, зовнішня реклама, спонсорство спортивних змагань, використання бренду компанії в назві стадіону, друкована реклама, що робить упор на бренд, і інтернет-реклама.

Проінформованість та брендінг - сприйняття споживачем певного продукту або послуги, іноді включає і компанії в цілому, наприклад Disney або Apple. Простіше кажучи, бренд формується завдяки маркетинговим діям компаній, власного досвіду використання продукту, а також рекомендацій друзів і колег. Брендінг дуже важливий: він змушує споживача звернути увагу саме на Ваші продукт або послугу. Крім того, він дозволяє компанії призначати націнку на свою продукцію (конкуренти зі слабким брендом цього робити не можуть). У стандартному циклі покупок від моменту створення проінформованості до 
безпосереднього придбання товару споживачем може пройти багато часу. Тому фінансові показники малозастосовні для вимірювання рівня обізнаності та маркетингу бренду. Компанії часто проводять широкомасштабні опитування 3 приводу обізнаності про бренд. Якісні дані збираються за допомогою опитувань великих вибірок споживачів (350 і більше осіб в кожному сегменті і географічному регіоні). Подібні заходи зазвичай забирають у компаній чимало часу i грошей. Тому великі організації оцінюють стан свого бренду не частіше 1-2 разів на рік.

Інші типові показники для вимірювання ефективності маркетингу, спрямованого на створення проінформованості, число заходів відвідувачів на сайт або розмір аудиторії інших медіа.

Наприклад, перемога Тайгера Вудса на кубку Masters в 2005 році забезпечила компанії Nike покази іiі логотипу на загальну суму 10,4 мільйона доларів, а перемога Джеффа Гордона на змаганні Daytona 500 у 2005 році забезпечила компанії DuPont показів на суму 9,9 мільйона доларів. Всього за 2005 рік завдяки спонсоруванню Джеффа Гордона компанія DuPont забезпечила собі покази логотипу на 85 мільйонів доларів. Проблема цих показників в тому, що вони ніяк не пов'язані з наміром здійснити покупку і не відображають ефективність маркетингу. Очевидно, що тут у наявності «розрив» між показами реклами і цінністю 3 точки зору маркетингу. Що вважати основним показником успішності для таких ситуацій? Головне - здатність споживача згадати Ваш продукт або послугу.

Показник 1. Основний показник оцінки обізнаності.

Проінформованість про бренд = Здатність згадати певний продукт або послугу.

Top-of-mind recall означає, що в рамках циклу покупки споживач, який розмірковує про придбання товару або послуги, згадає в першу чергу ваш продукт. Існують і інші, більш складні показники, пов'язані 3 проінформованістю, але всі вони в 
основному оцінюють здатність споживача назвати продукт або компанію.

Маркетинг, який формує оцінку споживача. Маркетинг оцінки впливає на намір споживача зробити покупку: він дозволяє порівнювати різні продукти або послуги. Приклади відповідних заходів - експертні висновки про продукти, друкована реклама 3 детальним зазначенням переваг і властивостей товару, брошури або сайти, які містять опис продукту. Наприклад, компанія Dell конкурує переважно на основі ціни: у неї є недорогий канал поширення (сайт) і унікальна система поставок (що дозволяє підтримувати низький рівень витрат). Ціна продукту займає важливе місце в маркетингу i часто фігурує в рекламі (де наводяться конкретні цифри і факти). Це відмінний підхід у випадках, коли основний критерій для клієнта ціна, він дозволяє споживачеві швидко оцінити конкуруючі продукти і зрозуміти, яке співвідношення ціни і якості буде для нього оптимальним.

Компанія Apple використовує інший підхід до маркетингу оцінки, роблячи акцент на дизайн i інноваційний характер продуктів. У рекламі iPhone підкреслюються переваги інноваційних технологій, наприклад App Store, одержали тисячі додатків для різних цілей. Apple впевнено та усвідомлено робить націнку на свої ноутбуки (продаючи їх за значно завищеною ціною, ніж Dell) і ігнорує питання ціни в маркетингових заходах: наприклад, Ви не побачите на сайті Apple ціни до тих пір, поки не почнете підбирати для себе комп'ютер 3 конкретними параметрами.

Маркетинг оцінки дозволяє показати цінність пропозиції товару або послуги, їх переваги та відповідність ціни якості. С багато способів надання споживачеві потрібної інформації, однак методики маркетингових вимірювань завжди загальні. Основна проблема маркетингу оцінки полягає в тому, що між оцінкою і реальною покупкою є часовий розрив, який (залежно від продукту) може становити тижні або навіть місяці. Друга проблема - необхідність створити чіткий причинно-наслідковий зв'язок між маркетингом і реальною покупкою. Саме тому 
фінансові показники незастосовні в області маркетингу оцінки до тих пір, поки не з'являється можливість відстежити поведінку споживача, який спочатку побачив рекламу, а потім через якийсь час здійснив покупку.

Стандартні показники для маркетингу оцінки - обсяг завантаженої з сайту інформації про продукт або число людей, які побачили друковану рекламу. Однак вони недостатньо добре відображають рівень впливу маркетингу. Так як же можна визначити ефективність маркетингу оцінки в кількісних показниках? Відповідь проста: потрібно знайти показник, пов'язаний 3 майбутніми продажами.

Кожен, кому доводилося купувати автомобіль (нехай i старий), напевно заходив в автосалон, набирав там брошури 3 описом нових моделей відповідної категорії і уважно їх вивчав. Такі брошури та тематичні сайти - приклади маркетингу оцінки в автомобільному бізнесі. У чому цінність яскравої і красивої брошури? Зрозуміти їі досить складно, однак ми можемо знайти показник, що вимірює намір зробити покупку в майбутньому i визначає рівень впливу маркетингу оцінки. Йдеться про тест-драйв.

Виявляється, ті, хто бере участь в тест-драйві, частіше купують машину. Не всі, але багато. Вимірявши число тестдрайвів і кількість їх учасників, які згодом купили автомобіль, ми можемо розрахувати середню ймовірність покупки: кількість покупок потрібно розділити на кількість тест-драйвів. Ще один вартий уваги показник - кількість відвідувачів салону. Чим більше відвідувачів, тим більше тест-драйвів, а отже, тим вище ймовірність покупки. Це схоже на те, як ведуть рахунок тренери в американському футболі. Основний показник для них - не реальний рахунок, а кількість «перших даунів». Якщо команда отримає можливість забезпечити собі достатню кількість «перших даунів», вона зможе рано чи пізно заробити багато очок i виграти матч. Тест-драйв - головний показник, пов'язаний 3 майбутніми продажами.

Показник 2. Основний показник споживчої очінки 
Тест-драйв = Тестування споживачем продукту або послуги до здійснення покупки.

Маркетинг лояльності. Маркетинг лояльності може включати в себе «консьєрж-супровід», наприклад в компанії Nordstrom. Ця служба допомагає у виборі покупок особливо цінним клієнтам. Інший приклад проактивний маркетинг, заснований на подіях. Так, компанія Jiffy Lube розсилає споживачам пропозицію про заміну масла після того, як ті проїжджають на автомобілі 5000 кілометрів. Крім повторного продажу, основний показник лояльності - рівень відтоку споживачів [1].

\section{Показник 3. Основний показник лояльності}

Відтік = Частка споживачів, які припиняють купувати Ваші продукти або послуги, зазвичай вимірюється за рік.

Відтік споживачів - дуже цікавий показник, вплив якого на деякі галузі особливо високо відчувається. Наприклад, у сфері продажів мобільних телефонів в США відтік становить в середньому $22 \%$ на рік.

Компанії, які не знають, хто їхні клієнти, часто не знають i коефіцієнт їх відтоку. В результаті в майбутньому їх чекає великий сюрприз - відтік може сягати 70-85\%. I це катастрофічні наслідки для бізнесу [2].

\section{Література:}

1. Марк Джефрі. Маркетинг, основанный на данных. 15 показателей, которые должен знать каждый. Москва : Видавництво «Манн, Іванов та Фербер», 2013. С. 82-93.

2. Йенс Нордфальт. Ритейл-маркетинг. Практики и исследования. Москва : Альпина паблишер, 2018. С. 181-183 